\title{
THE APPLICATION OF LEGAL CONSTRUCTION IN THE RULINGS OF THE CONSTITUTIONAL COURT
}

\author{
Bisariyadi* \\ Center for Research, Case Review and IT Management (Pusat P4TIK), \\ Mahkamah Konstitusi Republik Indonesia \\ Jalan Medan Merdeka Barat No. 6, Jakarta Pusat, 10110
}

\section{Abstract}

The Constitutional Court does not only interpreting the Constitution in judicial review cases. The Court also applies legal construction which include constitutional construction and statutory construction. This article aims to identify this approach in the Court rulings. It also seeks to find conditions that trigger the Court to venture on discovering the law by applying legal construction.

Keywords: The Constitutional Court, interpretation, constitutional construction, statutory construction.

\section{Intisari}

Mahkamah Konstitusi tidak hanya menafsirkan Undang-Undang Dasar dalam perkara pengujian UndangUndang. Mahkamah Konstitusi juga melakukan pendekatan konstruksi hukum dalam konteks konstruksi konstitusi maupun konstruksi undang-undang. Tulisan ini bertujuan untuk melakukan identifikasi putusan-putusan Mahkamah Konstitusi yang menggunakan konstruksi hukum. Selain itu, tulisan ini juga dimaksudkan untuk mencari faktor-faktor yang mendorong Mahkamah Konstitusi melakukan konstruksi hukum.

Kata Kunci: Mahkamah Konstitusi, penafsiran, konstruksi konstitusi, konstruksi undang-undang.

\section{Pokok Muatan}

A. Introduction 136

B. Discussion 136

1. Distinction of Interpretation and Construction 136

2. The Usage of Construction in the Court's Rulings 140

C. Conclusion 146 


\section{A. Introduction}

The rulings of the Constitutional Court (the CC or Mahkamah Konstitusi) can spark public debates. It is not rare to find a voice of dissent towards the rulings by politician or scholars but among them there were also supporters of the Court rulings. The debate gets even more intense whenever the Court issued a "conditionally (un)constitutional" ruling. Those who disagree with the approach by the Court argues that it overstepped the Court's constitutional mandate. The Parliament even gets more agitated with the issuance of an amendment to the Law on the CC. ${ }^{1}$ It is a political move to control the Court.

Apart from political debate and academic discourse, the Court has a number of rulings that are not only "to grant", "to annul" or "non-admission" of the petition. A study is dedicated to identify and offers categorization of these atypical rulings of the CC. ${ }^{2}$ But other than that, scholarship on the topic is a rarity, in particular with regards to the issue of how the Court or judges discover the law. In criminal, private and administrative law, this topic has been well developed. Yet, the discourses on legal construction in constitutional law, in Indonesia, is still left vacant.

This article aims not to fill in the open room of that scholarship, for it is too ambitious with such limited space. It will present an argument in the context of the CC's rulings. The rulings not only consist of interpretation but the Court also perform legal construction, as it will later be discuss. The distinction between interpretation and construction is not fully explored by the Indonesian legal scholars although the term is widely used. Therefore, in the beginning, it will review theoretical discourse in the Indonesian context on the distinction between interpretation and construction. The next chapter of the article will elaborates rulings wherein the Court apply legal construction. The Court objective to reconstruct the Law was to fill existing legal vacuums. In addition, it also explores circumstances which influence the $\mathrm{CC}$ to utilize legal construction.

\section{B. Discussion \\ 1. Distinction of Interpretation and Cons- truction}

The distinction between interpretation and construction has been discussed by the legal scholars and become a classical study. The diversity of legal system amongst countries contributes to this distinction. The civil law system provides a different legal interpretation from its brethren, the common law. This difference contributes a variety of nuance in creating legal norms. ${ }^{3}$ Some argue that the distinction between interpretation and construction is based on scholar's respective impulse towards a certain legal system. In civil law countries, interpretation and construction are intermingled, whereas countries that adopted common law system are unequivocal in their distinction. ${ }^{4}$

In civil law countries, such as Indonesia, interpretation and construction are considers as part of the methods that judges use in their quest to find law (rechtsvinding). However, there is a discrepancy in Indonesian scholars on the methods that are constituted as construction. Sudikno Mertokusumo

The DPR have issued an amendment to the Law on the CC (Law No. 8 of 2011). Article 57(2a) of the Law stipulated that the ruling of the CC may not contain

(a) ruling other than "to grant" or "to annul" the petition and declaration that the petition is "inadmissable",

(b) order to legislators; and

(c) formulating a new text.

However, this article was annuled by the CC in the ruling No. 48/PUU-IX/2011.

Atypical ruling may define as a type of decision wherein the Court panel use a different approach for the dictum rather than to apply the type of dictum as set forth in the Law of the CC. The study recorded 108 rulings (issued from 2003 to 2015) which divided into 4 categories, namely: (1) adding new norms; (2) modifying existing regulations; (3) suspending the enforceability of the ruling; and (4) to fill legal vacuums. See more in Bisariyadi, "Atypical Rulings of the Indonesian Constitutional Court", Hasanuddin Law Review, Vol. 2, Issue 2, August 2016.

William Tetley, Mixed Jurisdictions: Common Law vs Civil Law (Codified and Uncodified), as cited in Gunawan Widjaja, Lon Fuller, "Pembuatan Undang-Undang dan Penafsiran Hukum", Law Review Fakultas Hukum Universitas Pelita Harapan, Vol. VI, No. 1 July 2006, p. 31.

4 Achmad Ali, 2002, Menguak Tabir Hukum (Suatu Kajian Filosofis dan Sosiologis), Gunung Agung Tbk, Jakarta, p. 144. 
opined that construction is also referred to as "exposition". Mertokusumo referenced to the opinion of Alida Maria-Bos, who define exposition as "a method which constructs words or forms a definition, as opposed to describing an object". 5 Exposition is set apart from other logic as analogy, appeal from the contrary (argumentum a contrario), and confining the meaning of text. This set of logic falls into comparative reasoning, therefore interpretation and analogy cannot be discrete. ${ }^{6}$ On the other side, some legal scholars argue that analogy, a contrario and confinement of text are construction. ${ }^{7}$ Regardless the different opinion among scholar on what consist of construction, they share the same opinion that legal construction is use by any courts or judges in the absence of law. ${ }^{8}$ It is employed to fill the gap.

In common law countries, especially in the United States, there are many scholarly literatures that discusses the distinction between interpretation and construction. It also developed in the constitutional law. ${ }^{9}$ For instance, Keith Whittington authored two books which discussed on the topic of constitutional interpretation ${ }^{10}$ and constitutional construction. ${ }^{11}$ Other scholars, such as Lawrence
B. Solum, ${ }^{12}$ Randy Barnett, ${ }^{13}$ and Laura Cisneros ${ }^{14}$ also published scholarly reviews which focus on the difference between interpretation and construction.

This notion had been around in the US since early 1800 s. Among the first person who talk about interpretation and construction is Francis Lieber. He argues that hermeneutics is a branch of legal science which discusses principles and rules on interpretation and construction. ${ }^{15} \mathrm{He}$ also offered nine fundamental principles and sixteen general principles on construction. ${ }^{16}$ These principles serve as regulatory instruction to understand text that requires interpretation or construction.

The difference between interpretation and construction can be observed from various perspectives. From methodological view, interpretation is analogous to historical approach or intention of drafters of the text (originalist), whereas other methods (non-originalist) fall as construction. Yet distinction from this perspective can be blurred since the spectrum of variation between originalist and non-originalist is diverse..$^{17}$ A perspective that offers a clearer distinction is by examines the process of finding meaning and the manifestation thereof. Lawrence B. Solum offers a definition of limitation

Alida Maria-Bos, Over Methoden van begripsvorming in het recht. (AE.E Kluwer Deventer) as cited in Sudikno Mertokusumo, 2014, Penemuan Hukum Sebuah Pengantar, Cahaya Atma Pustaka, Yogyakarta, p. 94.

Sudikno Mertokusumo, Ibid., p. 95.

Jimly Asshidiqie, 1997, Teori \& Aliran Penafsiran Hukum Tata Negara, ed. I, Ind. Hill Co., Jakarta, p. 17-18; also see Jazim Hamidi,2011, Hermeneutika Hukum Sejarah - Filsafat dan metode tafsir, revised edition, UB Press, Malang; Also see Ph. Visser't Hoft, Penemuan Hukum, (Rechtsvinding), translated by B. Arief Sidharta, 2001, Laboratorium Hukum FH Univ Parahyangan, Bandung.

Jazim Hamidi, Ibid., p. 52-53; See also Sudikno Mertokusumo, Op. cit., p. 87.

In Common Law countries, statutory interpretation is set apart from constitutional interpretation. See James Allan Senior, "Constitutional Interpretation v. Statutory Interpretation", Legal Theory, March 2000, p. 109-122; see also Kent Greenwalt, Constitutional and Statutory Interpretation, in Jules Coleman, Kenneth Einar Himma and Scott J. Shapiro (eds), 2014, The Oxford Handbook of Jurisprudence and Philosophy of Law, Oxford University Press, Oxford.

On the other hand, Civil Law countries only recognize "statutory interpretation" without any distinction to the constitutional interpretation. The constitutional interpretation is merely a specific form of statutory interpretation, see Heinrich Scholler, "Notes on Constitutional Interpretation", Paper, January 2004 (limited publication by Hanns Seidel Foundation Indonesia).

10 For further analysis see Keith Whittington, 1999, Constitutional Interpretation: Textual Meaning, Original Intent, and Judicial Review, University Press of Kansas, Kansas.

11 Also see literature written by Keith Whittington, 1999, Constitutional Construction: Divided Powers and Constitutional Meaning, Harvard University Press, Cambridge.

12 Lawrence B. Solum, "The Interpretation-Construction Distinction”, Constitutional Commentary, Vol. 27, 2010 , p. 95.

13 Randy Barnett, "Interpretation and Construction", Harvard Journal of Law and Public Policy, Vol. 34, 2011, p. 65-72.

14 Laura A. Cisneros, "The Constitutional Interpretation/Construction Distinction: A Useful Fiction", Constitutional Commentary, Vol. 27, 2010, p. 71.

15 Francis Lieber, 1839, Legal and Political Hermeneutics: Principles of Interpretation and Construction in Law and Politics, 3rd edition, Charles C. Little and James Brown, Boston, p. 55.

16 As quoted in James Farr, Amerikanisasi Hermeneutika: Legal and Political Hermeneutics karya Francis Lieber, in Gregory Leyh (ed), 2014, Hermeneutika Hukum: Sejarah, Teori dan Praktek, Nusa Media, Bandung, p. 141-145 (translation by M Khozim).

17 The difference between originalists and non-originalist is a reality in constitutional law in the United States For a detailed discussion, see Laura A. Cisneros, Op. cit., p. 72. 
interpretation and construction in constitutional law. He define that

Constitutional interpretation is the activity that discerns the communicative content (linguistic meaning) of the constitutional text. Constitutional construction is the activity that determines the content of constitutional doctrine and the legal effect of the constitutional text. ${ }^{18}$

These approaches appear identical. Both attempt to find the meaning of legal text. However, in terms of process, constructing is a step further then interpreting. Construction not only focuses on the meaning of a word or a phrase but also to produce a legal doctrine to be applied.

The difference between construction and interpretation may be drawn between the terms "vagueness" and "ambiguity". Solum argues that "... ambiguities in legal texts can be resolve by interpretation, but vagueness always requires construction." 19

Article 18 (4) of the 1945 Constitution set a perfect example of ambiguous text in the Constitution. The phrase "democratically elected" which incorporated in the Article stipulate the condition by which regional government has to held the election of its head of government. The term "democratically" is ambiguous since it may have meaning that the election can be held through direct or indirect election. Both are considered as democratic.

It is become an issue when a number of citizens lodged a petition to the $\mathrm{CC}$ on how the term "democratically elected" has to be interpreted. ${ }^{20} \mathrm{In}$ its ruling, the Court took an originalist approach. It considered the opinions of the members of the People's Representative Assembly (Majelis Permusyawaratan Rakyat or MPR) who drafted the Amendment of the Constitution. The Court find that there was a political agreement in the MPR that the term "democratically elected" is intentionally formulated to be ambiguous. The reason behind this arrangement is to accommodate the design of election in special or autonomous regions. Therefore, it is practically impossible to have a uniform design of the head of regional government election. The phrase offer space for the lawmakers to design the most appropriate election mechanism in each region. ${ }^{21}$ The $\mathrm{CC}$ recognized the ambiguity of the phrase in Article 18(4) of the Constitution and allowed the lawmakers to have final decision whether to held direct or indirect election. Both have constitutional ground.

In another ruling, the Court not just interpret but also reconstructs an Article of the Constitution due to the vagueness of its text. It can be found in the Court ruling which examine electricity case. ${ }^{22}$ The Court have to construct the phrase "controlled by the state" as stipulated in Article 33 (3) of the 1945 Constitution. The term is not ambiguous. It is vague. What does it mean by "controlled by the state"? There is no legal doctrine to be applied as measurement to this term. The Court, then, reconstructed it and holds that

$[\ldots]$ the phrase "controlled by the state" must be interpreted to an extensive state's control, which originated from the sovereignty of the Indonesian people, over its assets on "earth and water and the natural resources contained therein", including the recognition of the public ownership by the people over the aforementioned assets. People, in mutual, as constructed by the 1945 Constitution give mandate to the state to make policies (beleid) and administer (bestuursdaad), regulate (regelendaad), manage (beheersdaad) and oversee (toezichthoudensdaad) in order to achieve the furthest possible welfare for the people. $^{23}$

\footnotetext{
Lawrence B. Solum, "Originalism andConstitutional Construction", Fordham Law Review, Vol. 82, 2013, p. 457.

19 Lawrence B. Solum, "The Interpretation-Construction Distinction", Op. cit., p. 98; meanwhile on the distinction between "vague" and "obscure" on the difference of phrases is "Ambiguity refers to words that have more than one sense or meaning. Vagueness refers to the penumbra or borderline of a word'smeaning, where it may be unclear whether a certain object is included within it or not." see Randy Barnett, Op. cit., p. 67.

20 The Constitutional Court Ruling No. 072-073/PUU-II/2004 on the Judicial Review on Law No. 32 of 2004 on Local Government.

Ibid.

The Constitutional Court Ruling No. 001-021-022/PUU-I/2003 on Review of Law No. 20 of 2002 on Electricity. Ibid.
} 
The CC's construction over the terms "controlled by the state" became a legal doctrine. First, it serves as a measure to review the state policy on electricity. In electricity case the Court held that the state's right to control important and vital commodities does not necessarily signify that the state must own $100 \%$ of corporate shares as long as the management (beheersdaad) of the corporation is in the state's hand. ${ }^{24}$ Therefore, privatization is permitted only if the state still holds primary authority to decide company policies.

The objective of legal construction is to fill legal gaps. ${ }^{25}$ It is inevitable since every country are experiencing legal gaps. It is included in the constitutional law. The gaps indentified in different terms (in example: legal vacuum, legislative ommissions). It results in a myriad of issues in comparative approach. The Conference of European Constitutional Courts held a conference in June 2008 that was intended to discuss the issue of legal vacuum that occur in European states. ${ }^{26}$ The Conference Reports revealed that the existence of legal vacuum is due to objective and subjective factors. ${ }^{27}$ The objective causative of legal gaps means that the ever-changing dynamics of society moving at a more faster pace that the creation of rules. Thus, legal norms will always be a lag behind. The subjective causative means that it put emphasize on the lawmakers. It is because of the inability of lawmakers to anticipate development that create gaps between law and society.

However, Hans Kelsen has a different opinion. He argues that legal gap is inconceivable. Gap cannot manifest from the absence of a norm.
When there is not any law regulate on a certain condition that occurs then such condition is not necessarily a legal gap. The law simply has not been extended towards the phenomenon, thus this does not mean that the law is absence. This approach proposes that a phenomenon that is not explicitly prohibited, in nature, is permitted. ${ }^{28}$ Kelsen opined

It is the fiction that the legal order has a gap, meaning that prevailing law cannot be applied to a concrete case because there is no general norm which refers to this case. The idea is that it is logically impossible to apply the actually valid law to a concrete case because the necessary premise is missing. ${ }^{29}$

In Indonesia, legal gap is considered identical to the term rechtsvacuum. But, some legal scholars contend that the term rechtsvacuum is not similar to legal gap. They coined another term. ${ }^{30}$ To put in context, the term refers to the absences of regulations. ${ }^{31}$ The legal system in Indonesian which adopted codified laws have a strong possibility of gaps due to the absence of regulations. Consequently, individual citizens or legal entities may raise a question in the application of judicial review to the CC.

The authority of the $\mathrm{CC}$, in nature, is to review the Law in conformity with the Constitution. This mechanism is intended to serve as a compelling tool to ensure that lawmakers adhere to constitutional values. Therefore, it upholds constitutionalism which is required in a constitutional democratic state in accordance with the rule of law. ${ }^{32}$ The constitutional mandate of the $\mathrm{CC}$ is to conduct a review. Yet, the nature of the task itself has shifted. In a number of rulings, the Court not only interprets the text of the Constitution but also tends to apply

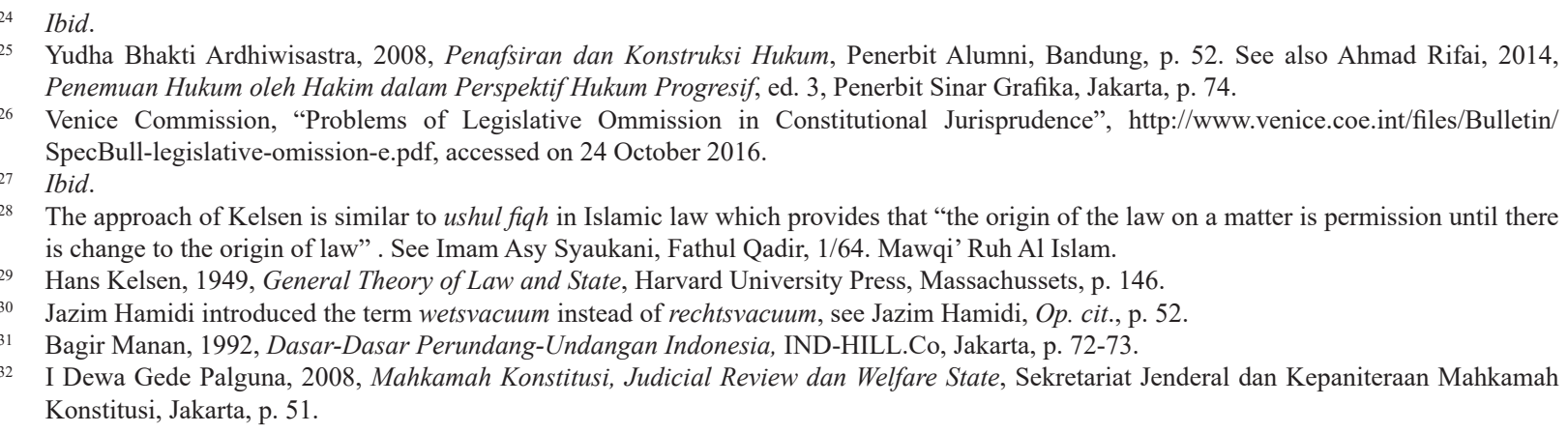


legal construction. The application of construction not only in terms of constitutional construction but the Court also extend it reconstruct the norms in the Laws.

\section{The Usage of Construction in the Court's Rulings}

The Court's opinions in judicial review cases contain interpretation or construction of the text in the Constitution. But more so often that the Court reconstruct the challenged article in the Law. It means that the Court also perform a statutory construction.

\section{a. Constitutional Construction}

The steps that are taken by the Court in the consideration of judicial review cases, firstly, is to deals with the constitutional issues beforehand. Hence, the Court need to see whether an article in the Constitution was vague or ambiguous. Afterward, the Court will examine the case and use the interpretation or construction of the Constitution to measure the constitutionality of the Law under reviewed. This referred to as legal construction at constitutional level. As it has been discuss earlier, in electricity case, the Court reconstruct the meaning of the terms "controlled by the state" in Article 33 (3) of the 1945 Constitution.

In addition, the Court must examine the question on whether presidential election and members of legislative election must be held in separate or simultaneous. This question was raise in consideration of the article in the Law of Presidential Election was challenged. The article stipulated that "The election for President and Vice President is held after the election for members of legislative." ${ }^{33}$ Furthermore, constitutional convention, as practice in the 1999, 2004 and 2014 elections, shows that presidential election and legislative election were schedule in a different period. Nonetheless, the Constitution is silent on the issue.

There are two Court's ruling regarding this issue. In the first ruling, the CC held that the existing practice wherein presidential election held after the election for parliament members consider as a political custom (desuetudo) that took place of laws, which is silent on the issue. ${ }^{34}$ Due to public acceptance, the custom is not breaching any laws even if it lacks on constitutional ground. ${ }^{35}$ Implicitly, the $\mathrm{CC}$ recognizes the existence of legal vacuum or lack of constitutional legitimacy on how the mechanism of both elections should be held.

However, the law was challenge for the second time. ${ }^{36}$ Against the first ruling, the Court offered a different opinion. ${ }^{37}$ The majority of the Court altered the first judgment. The $\mathrm{CC}$ argue, in the second ruling, that constitutional custom as considered in the previous Court's ruling is not similar to a constitutional text to be set as to determine

\footnotetext{
Article 3 (5) of Law No. 42 of 2008 on Presidential Election that was examined by the Constitutional Court Ruling on case Number 14/PUU$\mathrm{XI} / 2013$.

The Coonstitutional Court Ruling on case Number 51-52-59/PUU-VI/2008.

Ibid.

The Constitutional Court Ruling on case Number 14/PUU-XI/2013.

The composition of the panel of judges who ruled on the two rulings is difference. The panel of judges who ruled on Ruling No. 51-52-59/ PUU-VI/2008 is Moh. Mahfud MD., Maruarar Siahaan, Maria Farida Indrati, Achmad Sodiki, Abdul Mukthie Fadjar, M. Akil Mochtar, M. Arsyad Sanusi, and Muhammad Alim. While, the composition of the panel of judges who ruled on Ruling Number 14/PUU-XI/2013 is Moh. Mahfud MD, Achmad Sodiki, M. Akil Mochtar, Hamdan Zoelva, Muhammad Alim, Ahmad Fadlil Sumadi, Maria Farida Indrati, Harjono, and Anwar Usman. There are four constutional judges who were present in the two rulings: Moh. Mahfud MD, Maria Farida Indrati, Achmad Sodiki and Akil Mochtar. In the first ruling (Ruling No. 51-52-59/PUU-VI/2008), three constitutional judges were dissent: Abdul Mukthie Fadjar, Maruarar Siahaan dan M. Akil Mochtar. Therefore, in the second ruling only Akil Mochtar stay with his opinion while Moh. Mahfud MD, Maria Farida Indrati, and Achmad Sodiki changed their stances.
} 
constitutionality of law. The binding force of custom of convention is similar to a moral reading of the Constitution. The Court also coined the term "constitutional morality". ${ }^{38}$ In its second ruling, the $\mathrm{CC}$ reconstructed Article 6A (2) and 22E (2) of the 1945 Constitution. Beforehand, the Court considers three related factors on the issue, namely (1) relationship between electoral system and presidential system as form of governance, (2) the intention of the Amendment of 1945 Constitution drafters, (3) the efficiency of electoral management, and the right of citizen to use their vote wisely. ${ }^{39}$ In conclusion, the $\mathrm{CC}$ reconstructs the text of the Constitution and held in a majority that presidential and member of legislative elecion must be held on the same day.

The second ruling of the Court was supported by a number of legal scholars. Former Chief Justice of the CC, Jimly Asshiddiqie, expressed his support of the Court's ruling where he endorses that the ruling would implied to the strengthening of presidential system. ${ }^{40}$ But there are also scholars who have opposing views, as voiced one of them by Yusril Ihza Mahendra. ${ }^{41}$

Apart from the academic debate, the Court's ruling will have its binding force to be applied in 2019 election. Numerous preparations must be undertaken from installing the legal framework, reorganizing electoral institutions as well as preparation for election logistics. ${ }^{42}$

\section{b. Statutory construction}

The examination of judicial review case designates the $\mathrm{CC}$ to decipher the text of the Constitution. In terms of the vague and ambiguous terms in the Constitution, the Court must give an explanation to the text. The $\mathrm{CC}$ performs interpretation or construction. In this regards, the $\mathrm{CC}$ plays the role as final interpreter of the Constitution.

On the contrary, the Court also find that numerous article in the Constitution has a clear meaning which the Court need no further reading. ${ }^{43}$ In this context, the $\mathrm{CC}$ acted as guardian of the Constitution. The CC's role was to safeguard values and spirit of the Constitution so that the essence of the Constitution is consistently portrayed in every law and regulation.

In its role as guardian, the Court shall not be limited to the petition of applicants. It is arranged in accordance with their personal interest. The idea of the Court should not be bound by laws trouble the Parliament. It attempted to limit this notion. In the revision of Law on the CC, the lawmakers proposed that the CC shall not issue ruling in which it (i) contains dictum no other than what is challenged by applicants, (ii) contains order to lawmakers and (iii) contains formulations of a new norm. ${ }^{44}$ This provision was intended

The Constitutional Court Ruling on case Number 14/PUU-XI/2013.

Ibid.

40 Hukumonline, "Pemilu Serentak Bertingkat Perkuat Sistem Presidensial", http://www.hukumonline.com/berita/baca/lt5387e6702f78c/pemiluserentak-bertingkat-perkuat-sistem-presidensial, accesed on 11 October 2016. See also Zainal Arifin Hoesein, "Pemilihan Umum Serentak: Analisis terhadap Putusan Mahkamah Konstitusi Nomor 14/PUU-XI/2013”, Jurnal Veritas, May 2015, p. 2-30. Also see the opinion of Saldi Isra, “(Bukan) Putusan yang Hambar”, Kompas, 27 January 2014.

41 Liputan6, "Pemilu Serentak 2019, Yusril: Putusan MK Salah dan Memalukan", http://news.liputan6.com/read/817047/pemilu-serentak2019-yusril-putusan-mk-salah-dan-memalukan, accessed on 11 October 2016. Also see DPR, "Polemik Menjelang Pemilu 2014 dan Suksesi Kepemimpinan Nasional, http://www.dpr.go.id/doksetjen/dokumen/minangwan-seminar-Polemik-Menjelang-Pemilu-2014-dan-SuksesiKepemimpinan-Nasional-1432262788.pdf, accessed on 11 October 2016.

42 Electoral Research Institute Indonesia, "Position Paper Pemilu Nasional Serentak 2019", http://www.rumahpemilu.com/public/ doc/2015_02_03_08_18_33_POSITION\%20PAPER\%20PEMILU\%20SERENTAK\%202019.pdf, accessed at 11 October 2016.

43 Constitutional interpretation is analogous to interpretation method in Islamic Law. Al-Qur'an as the primary source of Islamic law contains verses that are muhkamat (the meaning is evident) and verses that are mutasyabihat (the meaning is vague and requires interpretation), as stated in QS 3:7.

44 As stipulated in Article 57 (2a) of Law No. 8 of 2011 concerning The Consttitutional Court (State Gazette of The Republic of Indonesia Year 2011 Number 70, Supplement to State Gazette of The Republic of Indonesia Number 5226). 
to cease the $\mathrm{CC}$ to issue atypical rulings. A form of atypical rulings by the Court was also known where it deliversa "(un)constitutionally conditional" ruling. The Court responded by repealing the law and that it is in accordance with the Constitution. It held that the law will impede the Constitutional Court from (i) conducting a review on constitutionality of norms, (ii) embed legal gap, and (iii) probing legal values and justice within society. ${ }^{45}$ An underline must be put in place where the Court argue that the consideration of issued such decision is to embed the existence of gaps in regulation.

The "(un)constitutionally conditional" ruling imply that apart from interprets the meaning of text, it also reconstructs the law. There have been 108 rulings in which the Court issue these type of rulings. Reconstruction of the text of laws by the Court includes where it insert new phrases or altering the existing text.

Considering various types of atypical rulings, the Court objectives to employ constructional approach are (1) to resolve vagueness of text in the law; (2) to embed legal vacuums; and (3) to protect and to give remedy of citizens constitutional rights impaired by government action due to the enforcement of laws.

\section{1) Redefine Vague Text}

One principle in drafting law and regulation is the clarity of content. ${ }^{46}$ If the formulation of the text in regulation is obscure then it is an infringement from a legal certainty. In a number of rulings, the Court held that a law is in contradiction to the Constitution due to the obscure formulation of the text in its content. And obscurity led to uncertainty. Therefore, the Court reformulates the text by inserting new phrases or altering the existing text.

In 2010, the Court issued a decision which drew public attention since, one of the reason, it was lodged by Yusril Ihza Mahendra, a former Justice Secretary. He filed a petition for a review of the Law on Attorney, especially with regards to the phrase "the end of term of Attorney General". ${ }^{47}$ The Law stipulated that Attorney General shall be released from the office by the end of his term. ${ }^{48}$ The phrase "by the end of his term" was considered to be obscure and resulted in uncertainty, in consideration of Mahendra. He posits that due to the obscurity in the text, he had suffered an injury to his constitutional rights.

$\mathrm{He}$, by the time the application was submitted, was named a suspect in the corruption case over the procurement of Legal Entities Administration System (Sistem Administrasi Badan Hukum or sisminbakum) ${ }^{49}$ A decision to named a person as a suspect is the authority of Attorney General. The case was brought up since the Attorney General terms of office, which at the time was held by Hendarman Supandji, was indeterminate. It was interconnected and closely linked to the changes of governmental administration after 2009 election, from Soesilo Bambang

45 The Constitutional Court Ruling No. 48/PUU-IX/2011.

46 Article 5 of Law No. 12 of 2011 on the Guideline for Drafting Laws and Regulations (State Gazette of The Republic of Indonesia Year 2011 Number 82, Supplement to State Gazette of The Republic of Indonesia Number 5234).

47 The Constitutional Court Ruling No. 49/PUU-VIII/2010 on the Review of Law No. 16 of 2004 on Attorney.

48 As stipulated in Article 22 (1d) of Law No. 16 Year 2004 concerning The State Attorney (State Gazette of The Republic of Indonesia Year 2004 Number 67, Supplement to State Gazette of The Republic of Indonesia Number 4401).

49 Detiknews, "Ini Kronologi Kasus Sisminbakum", http://news.detik.com/berita/1929720/ini-kronologi-kasus-sisminbakum, accessed at 11 October 2016 
Yudhoyono - Jusuf Kalla (2004-2009)

to Soesilo Bambang Yudhoyono Boediono (2009-2014).

Hendarman Supandji was appointed as Attorney General during the first presidential term of Soesilo Bambang Yudhoyono in 2007.50 Yudhoyono intended to maintain Hendarman Supandji as Attorney General in his second term. Therefore, the Decree on the dissolution of his first cabinet which was accompanied by a Decree on the formation of a new cabinet did not include the appointment of the Attorney General. ${ }^{51}$

Referring to the phrase "by the end of his term", as challenged by Mahendra, the Court describe that the term of office for Attorney General can be determined through four models: (1) according to the terms of office of the administration and/or the President; (2) according to certain period which different to the rest political appointees in the cabinet; (3) according to age limitation or pension and; (4) by the discretion of the President. ${ }^{52}$ The Court concluded that the possibility of these models resulted create uncertainty stemming from the obscure formulation of text.

The $\mathrm{CC}$ reconstructed the phrase "by the end of his term" and inserting new phrase where the Court formulate that "the Attorney General term of office is aligned with the President and the member of Cabinet term of office or can be dismissed from the office by the President." 53

In other rulings, the Court find indecisive content in Laws which encourage it to insert new text or alter them. There are two examples in the Law on Criminal Procedure where the Court find obscurity in the text. First, the phrase "third party" in relation to parties that allow inquiring legality of the termination of criminal procedure as stipulated in article 80 of the Law on Criminal Procedure. ${ }^{54}$ The Court held that "third party" may include victim or applicant, public independent institutions or communal organizations.

Second, the phrase "promptly" regarding the duration of arrest warrant copy be delivered to the family of the accused as stipulated in the Criminal Procedure Law. ${ }^{55}$ The Court reconstructed the text of the Law stating that the term "promptly" must be read "promptly and within seven days. ${ }^{56}$

\section{2) Embed Legal Gaps}

The Court embedded legal gaps which included in this group is not only in the context of to fill in the vacuums but also it consist of where the Court

Based on Presidential Decree Number 31/P Year 2007.

51 Due to the end of Presidential Term of 2004 - 2009 on 20 Oktober 2009, the President issued a Decree Number 83/P Year 2009 that dissolve Kabinet Indonesia Bersatu. Hendarman Supandji as Attorney General was not included on the dissolution decree. He also did not included in Presidential Decree Number 84/P Tahun 2009 on the establishment of Kabinet Indonesia Bersatu II (terms 2009 - 2014). The government argue that Hendarman Supandji as Attorney General was based on the decree of his appointment which was not release from the office in accordance to the Decree of the dissolution of Kabinet Indonesia Bersatu.

52 Constitutional Court Ruling No. 49/PUU-VIII/2010, Paragraph [3.31]

53 Ibid.

54 Article 80 Law 8 of 1981 on Criminal Procedure stipulated "Request to examine the legality of termination of investigation can be submitted by the investigator or attorney or the third party eith interest to the Head of the court and stipulating the condition"

See the Constitutional Court Ruling Number 98/PUU-X/2012

55 Article 18(3) Law No. 8 of 1981 on Criminal Procedure stipulated "Copy of arrest warrant as presribed in paragraph (1) must be delivered to the family promptly after the arrest"

56 The Constitutional Court Ruling No. 3/PUU-XI/2013. 
anticipated the possibility of gaps. As the result of the annulment of laws, especially the law as a whole, by the Court, there will be gaps and the Court require to fill the condition where the law was absent.

As an example is where the Court considered the absence of regulation in a certain condition as it happened in the head of local government election. The lawmakers when drafting the Law on Head of Local Government Election (Law No. 8 of 2015), intended to design the election must be held with the participation of more than one one candidate. Yet, reality speaks different words. In 2015 local election, there were four regions where only one candidate participated. They were in District of Blitar, District of Tasikmalaya, District of North Timor Tengah and City of Mataram. ${ }^{57}$ The condition is a perfect example of legal gaps due to the absence of regulation on the issue.

It was a constitutional issue in regards to the application to review the Law on single candidacy issue. ${ }^{58}$ In its ruling, the Court recognized the signs of vacuum where it stated: "...legal vacuum exist when the requirement of participated by at least two candidates is not fulfilled, in which the local election can not be held." ${ }^{59}$ The CC strongly contend that election must still be held with only a single candidate participates. It, then, reconstructed the law on the text. Furthermore, the Court also indicate that the ballot must be designed to give the opportunity for voters to the expression of "Agree" or "Disagree". ${ }^{60}$

In the later example is the rulings of the Court which reconstructed the law in the anticipation of gaps. These rulings tend to be found in rulings where the Court annulled the law as a whole. In this sort of condition, it inclined to reinstate the previous law that rules the same issue. For example, in electricity case, the Court annulled the Law on Electricity (Law No. 20 of 2002) and reinstated the previous Law (Law No. 15 of 1985). ${ }^{61}$ In a similar vein is in the instance of cooperation case $^{62}$ and in water resources case. ${ }^{63}$ There lies similarity in the review of those cases, wherein the Court reviewed an article within the Laws which considered as its "core". As consequences, the annulment of the aforementioned articles would make the law incoherent. The Court required to apply legal construction and not merely interpret.

\section{3) Redress Citizen Constitutional}

\section{Right}

The court main objective to apply legal construction is to give remedy to the rights of the citizens that have been damage. ${ }^{64}$ But, the issue lies in its unique adoption to assess the standing of an individual to be a party in judicial review case. The standing is

\footnotetext{
KPU, “Calon Tunggal, Perppu dan Kekosongan Hukum”, Suara KPU, July-August, 2015, p. 4.

Registered by the Court with Case No. 100/PUU-XIII/2015, filed by Effendi Ghazali.

The Constitutional Court Ruling No. 100/PUU-XIII/2015, paragraph [3.13].

Ibid

The Constitutional Court Ruling No. 001-021-022/PUU-I/2003 p. 350.

The Constitutional Court Ruling No. 28/PUU-XI/2013, paragraf [3.25]; the CC reinstate Law No. 25 of 1992 on Cooperation.

The Constitutional Court Ruling No. 85/PUU-XI/2013, paragraph [3.32]; the CC reinstate Law No. 11 of 1974 on Irigation.

Bisariyadi, "Yudisialisasi Politik dan Sikap Menahan Diri: Peran Mahkamah Konstitusi dalam Menguji Undang-Undang", Jurnal Konstitusi, Vol. 12, No. 3, September 2015, p. 483.
} 
classified as quasi actio popularis. ${ }^{65} \mathrm{It}$ is a mixture between normative review applied by individual citizen (actio popularis) and the application of standing requirement for an individual in a constitutional complaint case. An individual is required to demonstrate the existence or potential loss that has or will be suffered due to the enactment of the challenged laws. Consequently, the Court's rulings will restore the rights of the individual.

With this mixture of adoption between constitutional complaint and actio popularis, the Court's ruling on judicial review finds itself in between altering abstract norms as well as restoring the constitutional rights of citizens. In this position, the Court is expected to be thorough in its ruling in order to not only give remedy to the individual rights of the party but also to consider that the rulings may also cause an effect to whole society.

An example is where the court issued a ruling in electronic document and information law case ${ }^{66}$ as applied by Setya Novanto. ${ }^{67}$ In this ruling, the Court granted the applicant and reconstructed the related laws. ${ }^{68}$ To put it in a nutshell, the Court recognized that there is a flaw of the procedure on wiretapping, especially in recording a private conversation. Wiretapping is fundamentally an act of violation to the privacy. Therefore, the state must carefully design and regulate the activity. In this framework, the Court emphasized that interception, in which include recording, must be conducted in accordance with the law. ${ }^{69}$ For instance, it has to have court permission as a form of control and supervision to prevent misconduct. ${ }^{70}$

The ruling was later become the ground for the Honorary Council of the House of Representatives (Majelis Kehormatan Dewan DPR or MKD $D P R)$ to examine Novanto case on the allegation of breaching ethics as member of parliament. The MKD DPR, as refers to the Court's ruling, held that the recording, as the primary ground of evidence to examine Novanto, was acquired in an unlawful procedure. ${ }^{71}$ Subsequently, the right for privacy of Setya Novanto was restored.

In the same instance, the ruling sparks debate over a criminal case which drew public attention, popular as, "the murder with cyanide coffee". Closed-circuit Television (CCTV) recording was submitted as evidence by the prosecutor to charge the defendant,

65 Bisariyadi, "Constitutional Complaint atau Actio Popularis: Kedudukan Hukum Perorangan dalam Perkara Konstitusi”, Majalah Konstitusi, Desember 2015, p. 74.

66 The Constitutional Court Ruling No. 10/PUU-XIV/2016.

67 Setya Novanto, also a Speaker of the DPR, is coceide allegedly involve in bribery case, popular as "papa requested for share". Novanto was ask for PT. Freeport Indonesia shares and use President Joko Widodo name to increase the possibility of that shares. The request was recorded by the CEO of PT FI, Maroef Sjamsoeddin and the recording was submitted by the Energy and Mineral Resources Secretary, as evidence and

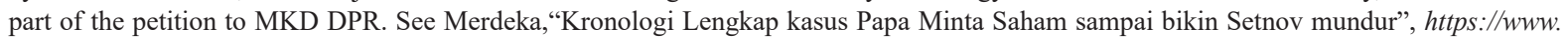
merdeka.com/peristiwa/kronologis-lengkap-kasus-papa-minta-saham-sampai-bikin-setnov-mundur.html, accessed at 24 Oktober 2016.

68 The Court ruled that the phrase "electronic Information and/or Document" as stipulated in Article 5 (1) and (2), Article 44b Law No. 11 of 2008 and Article 26A Law No. 20 of 2001 must be read especially in the phrase "electronic Information and/or Document" as an evidence before the Court in the request of police, attorney, and/or other law enforcement as prescribed in the Law in accordance to the Article 31(3) Law No. 11 of 2008 on Electronic information and transaction."

69 The Constitutional Court Ruling No. 20/PUU-XIV/2016, p. 92.

70 Ibid., p. 94.

71 Republika, "MKD Pulihkan Nama Baik Setya Novanto, Inilah Isi Suratnya”, Republika, Wednesday 28 September 2016, http://rmol.co/dpr/ read/2016/09/28/262382/MKD-Pulihkan-Nama-Baik-Setya-Novanto,-Inilah-Isi-Suratnya-, accessed at 24 October 2016. 
Jessica Wongso. The prosecutor indict Wongso had placed cyanide that has cause the death of Mirna Salihin. In reference to the same Court ruling, the defense lawyer argued that the CCTV recording was obtained by the prosecutor is not in accordance with the law. ${ }^{72}$

The ruling of the Court itself unfolded few possibilities. The Court argued that the acquisition of electronic information and/or document as evidence was requested by the police, prosecutor and/or other judicial institutions. In this context, the Court have narrowed the meaning of the text suggesting that electronic information and document can only be obtained in the request of law enforcement.

On the other hand, the Court also implied the possibility that electronic document, including recording, can be considered as legal evidence if the procedure of its acquirement is explained before the court (bewijsvoering). ${ }^{73}$ In other words, the Court emphasizes on the procedure of acquiring evidence as opposed to the actors of whom request the evidence.

The above are examples of the dilemma faced by the Court in the abstract review of law in abstract norm in conjunction to protect individual rights. A ruling of the Court to reinstate rights a citizen may not be applicable in another case. The nature of judicial review is its abstract character and its binding force to all citizens (erga omnes). Consequently, a ruling requires a holistic approach as well as judicial wisdom and craftmanship of constitutional judges in examination and rule on each and every constitutional issue.

\section{Conclusion}

The CC is the interpreter of the Constitution. In its authority to review the constitutionality of a law, the Court is bind not only interpret but also to apply legal construction. In such a context, the Court not only plays the role as "interpreter" function but also as "guardian" of the Constitution. In order to safeguard and oversee constitutional values, the Court obliged to reconstructed the laws. The numbers of rulings in which the Court utilized construction approach has grown in number. ${ }^{74}$

This research offers three conditions that require the Court to reconstruct the law, namely: (i) when the text in the law is obscure or vague; (ii) in order to fill legal gaps; and (iii) to reinstate citizen's constitutional rights. Furthermore, it also finds that the Court not only reconstructs the law or statutory construction but it also reconstructs the Constitutional text or constitutional construction.

This is a practice that requires thoroughness as well as creativity. The Court ruling needs to consist of comprehensive and convincing legal argument. The Court also required elaborating its legal reasoning which prompted it to take a construction approach. It is not an easy task since the only tool possessed by the Court in acquiring legitimacy over its ruling is its logic and rational in decision making. In the ruling where the Court alters a government policy the task even gets harder. Only in thorough and holistic argument that the Court find its legitimacy to change any policy and to alters any laws that are not in conformity with the Constitution.

\footnotetext{
Solopos, "Inilah Efek Setya Novanto yang Menguntungkan Jessica Wongso", http://www.solopos.com/2016/09/26/inilah-efek-setya-novantoyang-menguntungkan-jessica-wongso-756019, accessed at 24 October 2016.

The Constitutional Court Ruling No. 20/PUU-XIV/2016.

74 In reference to the ruling's dictum on conditionally (un)constitutional in comparison to the judicial review rulings from 2003-2015, the percentage is $12 \%$. In details, the "conditionally (un)constitutional" from 2003 to 2015 in total 108 rulings and judicial review case from 2003 to 2015 in total 858 rulings.
} 


\section{REFERENCES}

\section{A. Books}

Ali, Achmad, 2002, Menguak Tabir Hukum (Suatu Kajian Filosofis dan Sosiologis), Gunung Agung Tbk, Jakarta.

Ardhiwisastra, Yudha Bhakti, 2008, Penafsiran dan Konstruksi Hukum, Penerbit Alumni, Bandung.

Asshidiqie, Jimly, 1997, Teori \& Aliran Penafsiran Hukum Tata Negara, Ind. Hill Co, Jakarta.

Hamidi, Jazim, 2011, Hermeneutika Hukum Sejarah - Filsafat dan Metode Tafsir, UB Press, Malang.

Hoft, Ph. Visser't, 2001, Penemuan Hukum, (Rechtsvinding), (translation by: B. Arief Sidharta), Laboratorium Hukum FH Univ Parahyangan, Bandung.

Kelsen, Hans, 1949, General Theory of Law and State, Harvard University Press, Massachussets.

Manan, Bagir, 1992, Dasar-Dasar PerundangUndangan Indonesia, IND-HILL.Co, Jakarta.

Mertokusumo, Sudikno, 2014, Penemuan Hukum Sebuah Pengantar, Cahaya Atma Pustaka, Yogyakarta.

Palguna, I Dewa Gede, 2008, Mahkamah Konstitusi, Judicial Review dan Welfare State, Sekretariat Jenderal dan Kepaniteraan Mahkamah Konstitusi, Jakarta.

Rifai, Ahmad, 2014, Penemuan Hukum oleh Hakim dalam Perspektif Hukum Progresif, Penerbit Sinar Grafika, Jakarta.

Whittington, Keith, 1999, Constitutional Construction: Divided Powers and Constitutional Meaning, Harvard University Press, Cambridge.

1999, Constitutional Interpretation: Textual Meaning, Original Intent, and Judicial Review, University Press of Kansas, Lawrence.

\section{B. Articles Journal}

Allan Senior, James, "Constitutional Interpretation v. Statutory Interpretation", Legal Theory, Vol.6, No.1, Maret 2000.

Barnett, Randy, "Interpretation and Construction", Harvard Journal of Law and Public Policy, Vol. 34, 2011.

Bisariyadi, "Atypical Rulings of the Indonesian Constitutional Court", Hasanuddin Law Review, Vol. 2, Issue 2, August 2016. , "Yudisialisasi Politik dan Sikap Menahan Diri: Peran Mahkamah Konstitusi dalam Menguji Undang-Undang”, Jurnal Konstitusi, Vol. 12, No. 3 September 2015.

Cisneros, Laura A., "The Constitutional Interpretation/Construction Distinction: A Useful Fiction", Constitutional Commentary, Vol. 27, 2010.

Hoesein, Zainal Arifin, "Pemilihan Umum Serentak: Analisis terhadap Putusan Mahkamah Konstitusi Nomor 14/PUU-XI/2013, Jurnal Veritas, Mei 2015.

Solum, Lawrence B., "Originalism and Constitutional Construction", Fordham Law Review, Vol. 82. 2013.

"The Interpretation-

Construction Distinction", Constitutional Commentary, Vol. 27, 2010.

Widjaja, Gunawan, "Lon Fuller, Pembuatan Undang-Undang dan Penafsiran Hukum", Law Review Fakultas Hukum Universitas Pelita Harapan, Vol. VI, No. 1, July 2006.

\section{Magazines and Newspapers}

Bisaryadi, "Constitutional Complaint atau Actio Popularis: Kedudukan Hukum "Perorangan dalam Perkara Konstitusi", Majalah Konstitusi, December, 2015.

KPU, "Calon Tunggal, Perppu dan Kekosongan Hukum", Suara KPU, July-August, 2015.

Isra, Saldi, "(Bukan) Putusan yang Hambar", Kompas, 27 January 2014. 


\section{Articles in Books (with Editors)}

Farr, James, Amerikanisasi Hermeneutika: Legal and Political Hermeneutics karya Francis Lieber, in Gregory Leyh (ed), 2014, Hermeneutika Hukum: Sejarah, Teori dan Praktek, (translation by M Khozim), Nusa Media, Bandung.

Greenwalt, Kent, Constitutional and Statutory Interpretation, in Jules Coleman, Kenneth Einar Himma and Scott J. Shapiro (eds), 2004, The Oxford Handbook of Jurisprudence and Philosophy of Law, Oxford University Press, Cambridge.

\section{E. Internet Articles}

Detiknews, "Ini Kronologi Kasus Sisminbakum", http://news.detik.com/berita/1929720/inikronologi-kasus-sisminbakum, accessed at 11 October 2016.

Hukumonline, "Pemilu Serentak Bertingkat Perkuat Sistem Presidensial", http:// www.hukumonline.com/berita/baca/ lt5387e6702f78c/pemilu-serentakbertingkat-perkuat-sistem-presidensial, accessed at 11 October 2016.

Liputan6, "Pemilu Serentak 2019, Yusril: Putusan MK Salah dan Memalukan", http://news. liputan6.com/read/817047/pemilu-serentak2019-yusril-putusan-mk-salah-danmemalukan, accessed at 11 October 2016.

Merdeka, "Kronologi Lengkap kasus Papa Minta Saham sampai bikin Setnov mundur", merdeka.com, Thursday 17 December 2015, https://www.merdeka.com/peristiwa/ kronologis-lengkap-kasus-papa-mintasaham-sampai-bikin-setnov-mundur.html, accessed at 24 October 2016.

Republika, "MKD Pulihkan Nama Baik Setya Novanto, Inilah Isi Suratnya", http://rmol. co/dpr/read/2016/09/28/262382/MKDPulihkan-Nama-Baik-Setya-Novanto,Inilah-Isi-Suratnya-, accessed at 24 October 2016.

Rumahpemilu, Electoral Research Institute
Indonesia, "Pemilu Nasional Serentak 2019", http://www.rumahpemilu.com/public/ doc/2015_02_03_08_18_33_POSITION\%20 PAPER\%20PEMILU\%20SERENTAK\%20 2019.pdf, accessed at 11 October 2016.

Solopos, "Inilah Efek Setya Novanto yang Menguntungkan Jessica Wongso", http:// www.solopos.com/2016/09/26/inilah-efeksetya-novanto-yang menguntungkan-jessicawongso-756019, accessed at 24 October 2016.

Venice Commission, "General report of the XIVth Congress of the Conference of European Constitutional Courts on "Problems of Legislative Ommission in Constitutional Jurisprudence", $\quad$ http://www.venice.coe. int/files/Bulletin/SpecBull-legislativeomission-e.pdf, accessed at 24 October 2016.

\section{F. Regulations}

Law No. 16 Year 2004 concerning The State Attorney (State Gazette of The Republic of Indonesia Year 2004 Number 67, Supplement to State Gazette of The Republic of Indonesia Number 4401).

Law No. 8 of 2011 concerning The Consttitutional Court (State Gazette of The Republic of Indonesia Year 2011 Number 70, Supplement to State Gazette of The Republic of Indonesia Number 5226).

Law No. 12 of 2011 on the Guideline for Drafting Laws and Regulations (State Gazette of The Republic of Indonesia Year 2011 Number 82, Supplement to State Gazette of The Republic of Indonesia Number 5234).

\section{G. Others}

Scholler, Heinrich, "Notes on Constitutional Interpretation", article in limited publication by Hanns Seidel Foundation Indonesia, January 2004.

The Constitutional Court Ruling No. 001-021-022/ PUU-I/2003 on the Review of Law No. 20 of 2002 on Electricity, issued in 15 December 
2004.

The Constitutional Court Ruling No.072-073 / PUU-II/2004 on the Review of Law No. 32 of 2004 on Local Government, issued in 22 March 2005.

The Constitutional Court Ruling No. 51-52-59/ PUU-VI/2008 on the Review of Law No. 42 of 2008 on Presidential Election, issued in 18 February 2009.

The Constitutional Court Ruling No. 49/PUUVIII/2010 on the Review of Law No. 16 of 2004 on Attorney, issued in 22 September 2010.

The Constitutional Court Ruling No. 48/PUUIX/2011 on the Review of Law No. 35 of 2009 on Narcotics and Law No. 8 of 2011 on the Amendment of Law No. 24 of 2003 on the Constitutional Court, issued in 18 October 2011.

The Constitutional Court Ruling No. 28/PUUXI/2013 on the Review of Law No. 17 of 2012 on Cooperation, issued in 28 May 2014.
The Constitutional Court Ruling No. 3/PUUXI/2013 on the Review of Law No. 8 of 1981 on Criminal Procedure, issued in 30 January 2014.

The Constitutional Court Ruling No. 85/PUUXI/2013 on the Review of Law No. 7 of 2004 on Water Resources, issued in 18 February 2015.

The Constitutional Court Ruling No. 14/PUU$\mathrm{XI} / 2013$ on the Review of Law No. 42 of 2008 on Presidential Election, issued in 23 January 2014.

The Constitutional Court Ruling No. 100/PUUXIII/2015 on the Review of Law No. 8 of 2015 on the Amendment of Law No. 1 of 2015 on the Edict of Government Regulation in lieue of Law No. 1 of 2014 on Governor, Regent and Mayor Election, issued in 29 September 2015.

The Constitutional Court Ruling No. 20/PUUXIV/2016 on the Review of Law No. 11 of 2010 on Electronic Information and Transaction and Law No. 20 of 2001 on the Amendment of Law No. 31 of 1999 on Corruption Eradication, issued in 7 September 2016. 